\title{
Analisis Sistem Informasi Pengelolaan Arsip Vital Digital (e-arsip) di PT. Pertamina (persero) \\ Studi Kasus Praktik Kerja Lapangan \\ di Direktorat Manajemen Data Aset PT. Pertamina (persero) Tahun 2019
}

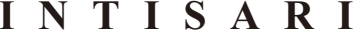

Sistem Informasi Pengelolaan Arsip menjadi salah satu bagian penting yang tidak terpisahkan dari kegiatan mengelola Arsip, terutama di lingkungan PT Pertamina yang dimulai tahun 2019 denganmembuat kebijakan untuk melakukan digitalisasi seluruh Arsip Vital yang dimiliki dan mengusung konsep paperless demi kemudahan dalam menggunakan dan memeliharanya. Analisis pada artikel ini didasarkan pada pengalaman praktik kerja lapangan yang dilakukan oleh penulis di Direktorat Manajemen Data Aset milik PT Pertamina. Metode yang dilakukan untuk menyusun artikel ini adalah dengan action research dan penelitian deskriptif. Sistem Informasi Pengelolaan Arsip yang dimiliki PT Pertamina adalah E-Arsip, yang dirancang untuk mengelola setiap Arsip Vital yang dimiliki PT Pertamina. Analisis yang dilakukan berdasarkan pada evaluasi melalui Assessment form yang dibuat dengan mengacu pada poin-poin penting dari Management of Electronic Records Guidance milik Archives and Records Management Division dari UNESCO PBB.Lembar penilaian yang dibuat menghasilkan evaluasi berupa penilaian, pengujicobaan serta masukan untuk bisa diimplementasikan kedalam sistem informasi E-Arsip. Terdapat 3 (tiga) subjek utama dalam lembar penilaian tersebut, diantaranya adalah administrasi \&keamanan, tampilan antar muka pengguna serta konten arsip. Lembar penilaian yang telah disusun dalam penelitian E-Arsip sudah cukup baik dan sangat layak digunakan untuk mengelola arsip vital dalam bentuk digital yang dimiliki oleh PT Pertamina.

\section{$\begin{array}{lllllllll}A & B & S & T & R & A & C & T\end{array}$}

System Information of Archival Management becomes one of the important thing that cannot be separated from the activities of managing records, especially in the PT Pertamina environment in which this year began to made policy about digitize all vital records and make the paperless concept for the easiness
PENULIS

Chrisna Adhi Pranoto, Samson CMS S.Sos., M.I.Kom., Nurmaya Prahatmaja S.Sos., M.A. Universitas Padjadjaran

chrisna16001@mail.unpad.ac.id samson.cms@unpad.ac.id nurmaya.prahatmaja@unpad.ac.id

\section{KATA KUNCI}

arsip digital, arsip vital, sistem informasi.

KEY WORDS

digital records, information system, vital records 
of use and preservation. The analysis contained in this article is based on author's internships experience in Directorate of Asset Data Management PT Pertamina. Research method that used in this article is action research and descriptive research. The system information that used by PT Pertamina is E-Arsip, in which designed for managing vital records of $P T$ Pertamina. Later on, the analysis would be based on evaluation through assessment form made by author referring to issues and guideline of Management of Electronic Records Guidance from United Nations. The assessment would implying the effectiveness and usability of the E-Arsip, then summarized in this article. There are 3 main subjects from the Assessment, there are Administration \& Security, Display User Interface and Archival Content. Overall results from assessment form, E-Arsip is good enough and can be used as a system information for managing digital records of vital records in PT Pertamina.

\section{PENGANTAR}

\section{Latar Belakang Masalah}

Pemanfaatan teknologi informasi untuk mengelola sumber daya pengetahuan dan aset yang dimiliki oleh suatu organisasi akan meningkatkan efisiensi pola kerja dan waktu yang diperlukan, sehingga akan mendukung perencanaan dan peningkatan kualitas organisasi tersebut. Hal ini sejalan dengan apa yang ada di PT Pertamina tentang sistem pengelolaan arsipnya, dimana Pertamina mengelola berbagai sumber daya aset informasi dari berbagai fungsi yang ada dalam lingkungan organisasinya. Salah satunya adalah bagian pengelolaan Arsip Vital dari aset perusahaan milik PT Pertamina berisi arsip-arsip yang selalu menjadi bagian yang tidak terpisahkan dari PT Pertamina itu sendiri, hal ini dikarenakan Arsip Vital akan sangat mempengaruhi keberlangsungan lingkungan kerja dari perusahaan tersebut. Arsip Vital adalah bagian dari arsip dinamis yang menjadi salah satu jenis arsip dengan tingkat kepentingan dan keharusan cukup tinggi untuk dikelola karena merupakan bagian dari keberlangsungan hidup suatu organisasi atau perusahaan.

Pengelolaan Arsip Vital perlu dilaksanakan secara baik dan terstruktur, hal ini sesuai dengan Undang-Undang (UU)Nomor 43 Tahun 2009 tentang kearsipan yang diharapkan mampu memberikan model dan skema mengenai tata kelola arsip beserta dengan instruksi pengelolaannya. Pada UU 43 tahun 2009 tercantum bahwa pengelolaan arsip perlu ditunjang dengan bantuan teknologi 
informasi yang memudahkan dalam mengelola dan mengatur penyimpanan dan sirkulasi dari arsip tersebut, sehingga penggunaan dan pemanfaatannya akan bisa lebih panjang serta terlindungi secara terus menerus.

Tata kelola arsip yang menggunakan perangkat teknologi informasi dengan bantuan sistem informasi akan diawali dengan penggunaan sistem perangkat lunak (software) tertentu yang akan menunjang proses pengelolaan dan pemeliharaannya secara digital. Perangkat lunak (software) yang digunakan harus sesuai dengan program kerja dan pengelolaan di perusahaan tersebut, yang mencakup pemenuhan kebutuhan untuk mengelola secara spesifik jenis arsip yang dimiliki dan juga standar operasional prosedur tentang penggunaan arsip yang dimiliki oleh perusahaan.

PT Pertamina merancang dan membangun sistem informasi pengelolaan arsip milik mereka sendiri dan dinamai dengan E-Arsip. E-Arsip dirancang dan dibangun dengan bantuan dari PT Astra Graphia Tbk. sebagai vendor pengelolaan arsip. Tahap pengelolaan arsip yang dilakukan oleh PT Pertamina pada saat penulis melakukan kegiatan praktik kerja lapangan disana adalah tim pengelola arsip masih dalam kegiatan pemindahan dokumen-dokumen fisik dari masingmasing gedung arsip PT. Pertamina
(Gedung Perwira dan Gedung Annex di Jakarta Pusat) ke Gedung Sentral Arsip yang ada di Plumpang, Jakarta Utara.Saat yang bersamaan, perancangan sistem informasi E-Arsip juga sedang berlangsung dan sudah pada tahap percobaan serta peluncuran ke mini server PT Pertamina.

Kegiatan pemindahan dokumendokumen fisik untuk digitalisasi memakan waktu yang cukup lama sehingga tahap ujicoba E-Arsip dilakukan secara maksimal selagi menunggu seluruh dokumen arsip vital milik PT Pertamina selesai dilakukan digitalisasi. Penulis melakukan kegiatan analisis serta evaluasi untuk membantu tim pengelola E-Arsip dalam mengembangkan sistem informasinya agar bisa mengelola arsip vital secara lebih efektif dan efisien.

\section{Metodelogi Penelitian}

Metodelogi yang digunakan dalam artikel ini adalah dengan pendekatan action research dan penelitian deskriptif. Penelitian action research menurut Sujarwadi (2014:10)adalah suatu penelitian yang ditujukan untuk menemukan metode paling efektif dalam kegiatan sehari-hari kegiatan yang dilakukan oleh suatu instansi, organisasi maupun perusahaan. Pendekatan metode penelitian ini diharapkan dapat membuat pembahasan lebih seimbang antara teori dan praktik sehingga hasil dari artikel ini 
dapat diterapkan dan diimplementasikan secara langsung kedalam sistem informasi E-Arsip. Pelaksanaan metode ini dilakukan dengan :

1. Identifikasi permasalahan pengelolaan arsip vital dengan E-Arsip;

2. Perencanaan kegiatan survei pengelolaan arsip vital dengan EArsip;

3. Pelaksanaan kegiatan praktik kerja lapangan di Direktorat Manajemen Aset;

4. Pemindahan dan digitalisasi dokumen fisik arsip vital; dan

5. Evaluasi sistem E-Arsip untuk pengelolaan arsip vital milik PT Pertamina kedepannya.

Metode penelitian yang kedua adalah dengan menggunakan metode penelitian deskriptif. Metode penelitian deskriptif adalah metode yang dilakukan dengan tujuan untuk mengungkap fakta suatu kejadian, objek, aktivitas, proses dan manusia secara "apa adanya" pada masa sekarang atau jangka waktu yang masih memungkinkan dalam ingatan responden (Prastowo, 2016:203). Penelitian ini dilakukan untuk memperoleh informasi secara deskriptif tentang fenomena maupun kejadian yang terjadi dalam tahapan pengembangan dan pengujicobaan perangkat sistem informasi E-Arsip. Melalui data deskriptif, penulis berharap dapat mengidentifikasi masalahmasalah serta peluang yang ada dalam proses tahapan ujicoba serta evaluasi sistem informasi E-Arsip agar bisa berkembang secara lebih efektif dalam menunjang kegiatan pengelolaan dan pemeliharaan arsip vital milik PT Pertamina. Metode penelitian deksriptif ini, penulis berharap dapat :

1. Menganalisis permasalahan dari sistem informasi E-Arsip dalam hal pengelolaan arsip vital;

2. Mengevaluasi sistem informasi EArsip dalam kemudahan serta keamanan dari pengelolaan arsip vital secara digital; dan

3. Mengusulkan untuk menambahkan fitur-fitur yang bisa membuat sistem informasi E-Arsip lebih efektif untuk digunakan untuk mengelola arsip vital.

\section{Kerangka Pemikiran}

Pembahasan yang ada dalam artikel ini akan berada dalam ruang lingkup sistem informasi serta pengelolaan arsip vital dari PT Pertamina secara digital dengan memanfaatkan Sistem Informasi E-Arsip.

Menurut Undang-Undang No.43 Tahun 2009 tentang Kearsipan dalam Bab 1 Ketentuan Umum Pasal 1, "Arsip Vital merupakan Arsip yang keberadaannya merupakan persyaratan dasar bagi kelangsungan operasional pencipta arsip, tidak dapat diperbarui, dan tidak tergantikan apabila rusak atau hilang". 
Arsip Vital menjadi bagian penting yang tak terpisahkan dalam suatu organisasi maupun perusahaan, karena arsip vital merupakan jenis arsip yang berkaitan langsung dengan keberlangsungan hidup dan operasional organisasi tersebut.

Keberadaan arsip vital menjadi sangat berarti dalam kelangsungan suatu organisasi, apabila terjadi kerusakan ataupun kehilangan arsip vital maka akan membuat kerugian yang sangat besar baik dari segi biaya maupun masalah hukum. Menurut Kemp (2017:xi) bahwa Arsip Vital sangat berpengaruh bahkan dalam kehidupan individu untuk memperingati dan memberikan suatu pemberitahuan akan kejadian yang memang benar-benar terjadi dan sah menurut undang-undang yang berlaku, seperti akta kelahiran, surat pernikahan, izin mengemudi dan lain-lain.

Setiap dokumen milik individu tersebut merupakan dokumen vital yang sangat dibutuhkan untuk melakukan beberapa hal yang dianggap legal dan sah secara hukum. Sehingga Arsip Vital ini sangat memberikan dampak yang besar bagi kelangsungan hidup dan perlu tindakan penanganan persiapan untuk mengelola Arsip Vital secara khusus agar Organisasi maupun individu yang memilikinya mampu menjaga dan mengambil tindakan pencegahan untuk memelihara Arsip Vital.

Sistem Informasi merupakan suatu komponen yang biasanya terdiri dari manusia, teknologi informasi serta kegiatan prosedur kerja yang memproses, menyimpan, menganalisis dan menyebarkan informasi untuk mencapai tujuan tertentu (Mulyanto, 2009:29). Definisi yang lain menyatakan bahwa sistem informasi adalah satu sistem yang diciptakan oleh manusia dan terdiri dari komponen-komponen dalam satu sistem organisasi agar bisa mencapai tujuannya yaitu untuk menyajikan informasi (Ladjamudin, 2005:39).

Berdasarkan kedua pendapat dari para ahli, pengertian dari sistem informasi adalah suatu komponen yang membentuk sistem terdiri dari manusia, teknologi informasi dan kegiatan prosedur kerja dengan terorganisir serta teratur yang mampu memproses, menyimpan, menganalisis dan menyebarkan informasi secara sistematis agar informasi dapat disebar dan disajikan secara efektif.

Sistem Informasi Kearsipan biasanya mengelola setiap arsip dan dokumen lain yang berkaitan secara sistematis dan terstruktur sehingga prosesnya dapat berjalan dengan efektif. Sistem Informasi Kearsipan merupakan bagian dari teknis dan fungsi pengelolaan arsip vital yang bermaksud untuk memelihara dan menjaga kaslian dan keutuhan berkas arsip vital.

Sistem Informasi Kearsipan dikembangkan oleh masing-masing pihak organisasi, menyesuaikan dengan skema 
pengelolaan yang telah ditetapkan sehingga penerapannya menyesuaikan dengan keadaan serta kondisi dari masingmasing pihak. Sistem Informasi Kearsipan biasanya akan berbentuk elektronik dan akan mengelola arsip-arsip yang berbentuk digital, sehingga setiap dokumen arsip yang ada akan disimpan dalam sebuah kabinet atau rak virtual dengan tujuan dapat ditemukan kembali secara cepat pada saat diperlukan.

Sukoco (2006:112) menyebutkan ada banyak sekali manfaat yang didapatkan jika menerapkan Sistem Informasi Kearsipan yang berbentuk elektronik dan digital, diantaranya adalah :

a. Dokumen Arsip lebih mudah untuk d i temukan kembali dan memungkinkan pemanfaatan arsip tanpa meninggalkan meja kerja;

b. Pengindekssan yang lebih fleksibel dan mudah dimodifikasi sesuai dengan ketentuan yang diberlakukan sehingga akan menghemat tenaga, waktu serta biaya;

c. Pencarian secara full-text, yang bisa mencari berkas berdasarkan kata kunci ataupun nama file dan akan tampil bentuk berkas secara full-text;

d. Berkas yang tersimpan memiliki kemungkinan yang kecil untuk hilang;

e. Menghemat tempat penyimpanan, karena rata-rata lembaran berkas akan berbentuk digital dengan ekstensi berkas .pdf dan gambar .jpg yang memiliki ukuran berkas lebih kecil (1 lembar dalam format pdf memiliki rentang ukuran $10 \mathrm{~KB}$ hingga $100 \mathrm{~KB}$ dan dalam format gambar akan memiliki rentang ukuran $500 \mathrm{~KB}$ hingga $2 \mathrm{MB}$ tergantung dari seberapa banyak konten yang dimuat);

f. Skema pengarsipan secara digital, sehingga meminimalisir resiko penggunaan kertas atau media cetak yang bisa rusak atau pudar termakan usia;

g. Pembagian Arsip kepada unit atau lembaga lain yang memiliki hak akses untuk berkas arsip tersebut bisa menjadi lebih mudah dengan pengiriman lewat LAN ataupun Internet;

h. Peningkatan Keamanan, sehingga akses terhadap pengelolaan Sistem Informasi Kearsipan secara digital hanya akan diberikan kepada otoritas pengelola dan pencipta arsip; dan

i. Mudah untuk melakukan restorasi atau pengembalian berkas apabila terjadi kesalahan pada saat melakukan pengelolaan, selain itu ada sistem backup yang memungkinkan untuk membuat dan menyimpan data cadangan yang lebih cepat serta aman.

Dari manfaat-manfaat tersebut, Sistem Informasi Kearsipan mampu menunjang aktivitas pengelolaan arsip secara lebih baik serta cepat. Hal ini dikarenakan pengerjaannya dilakukan 
secara digital dengan bantuan perangkat teknologi informasi sehingga upaya yang dilakukan bisa lebih mudah. Beberapa perangkat lunak (software) Sistem Informasi Kearsipan tersedia secara terbuka (open-source) di GitHub dan repository perangkat lunak lainnya, bahkan bisa dimodifikasi secara bebas sesuai dengan kebutuhan dari organisasi a t a u perseorang a y a $\mathrm{g}$ memanfaatkannya.

Efektifitas dari Sistem Informasi Kearsipan akan terukur dan dapat dinilai dari seberapa akurat dan aman koleksi arsip yang dikelola, sehingga setiap pergerakan dan sirkulasi arsip bisa terkontrol secara baik dalam hal penemuan kembali informasi (information retrieval) maupun rekam jejak audit arsip dalam hal transaksi. Sistem yang efektif akan memberikan dampak yang baik bagi hasi koleksi arsip maupun pengelolanya, sehingga penyusunan panduan penggunaan serta panduan kebijakan harus dibentuk pada saat perancangan sistem informasi itu juga.

\section{PEMBAHASAN}

\section{Arsip Vital PT Pertamina}

PT Pertamina memiliki banyak sekali dokumen untuk keperluan mereka dalam menjalankan organisasi serta produkisnya, beberapa diantara dokumen tersebut merupakan arsip vital. Arsip vital
PT Pertamina terbagi menjadi beberapa bagian, diantaranya adalah

1. Arsip Legal (Surat Perjanjian, Surat Kepemilikan Tanah dan Bangunan, Surat Kepemilikan Aset, Surat Keterangan Pegawai, Data Pribadi Pegawai dan beberapa surat yang berkaitan dengan hukum lainnya);

2. Arsip Rancangan Kerja (Peta, Blueprint, Surat Persetujuan Kerja, Denah Lokasi, Rancangan Pembangunan, Rancangan Pengembangan Aset) dan;

3. Arsip Dinamis Inaktif (Surat Keluar Masuk Perusahaan dan Catatan Tahunan).

PT. Pertamina mengusung konsep paperless untuk meningkatkan efisiensi penggunaan serta kemudahan dalam pemanfaatan arsip vital, hal ini dikarenakan arsip vital yang beragam dalam bentuk fisik dan jumlah yang kian bertambah setiap saat. Direktorat Manajemen Aset langsung membuat kebijakan untuk melakukan digitalisasi seluruh aset-aset arsip vital yang dimiliki PT Pertamina dan mengelolanya secara digital dengan menggunakan Sistem Informasi Pengelolaan Arsip Digital.

Selama melaksanakan kegiatan Praktik Kerja Lapangan penulis diberikan kesempatan untuk mencoba membantu proses kegiatan digitalisasi arsip vital PT Pertamina. Kegiatan digitalisasi dilakukan oleh PT Pertamina karena perusahaan 
ingin melestarikan dan mempertahankan informasi yang ada pada arsip-arsip vital tersebut. Pertamina dalam kegiatan proses digitalisasi arsip vital melakukan kerja sama dengan PT Astra Graphia Tbk, dikarenakan PT Pertamina (Persero) belum memiliki Sumber Daya Manusia (SDM) yang mumpuni untuk melakukan kegiatan digitalisasi arsip vitalnya. Kegiatan yang penulis lakukan di Direktorat Asset Data Management PT Pertamina (Persero) antara lain :

1. Melakukan sortir dan packaging arsip vital yang berisikan surat-surat berharga seperti surat tanah, surat bangunan, surat keterangan, surat keterangan pegawai, denah bangunan, denah lokasi, blue print bangunan dan peta lokasi. Kegiatan ini dilakukan di Gedung Perwira dan Gedung Annex PT. Pertamina yang berlokasi di Jakarta Pusat; dan

2. Membantu kegiatan quality check terhadap berkas-berkas arsip vital yang sudah di sortir berdasarkan Daftar Arsip Sementara (DAS) yang sudah dibuat sebelumnya, agar arsip yang akan digitalisasi sesuai dengan jumlahnya, dikarenakan beberapa arsip memiliki salinan/copy-an.

Setiap arsip yang telah disortir dan dilakukan pengecekan akan disimpan di tempat penyimpanan yang khusus untuk melakukan digitalisasi arsip. Proses digitalisasi dilakukan dengan mengecek

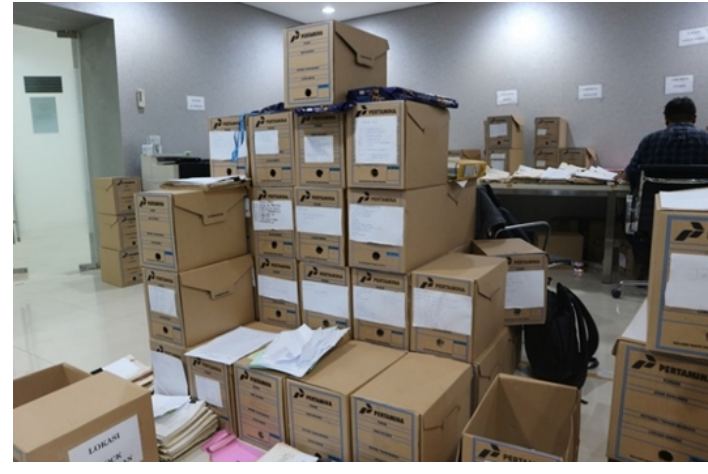

Foto 1

Arsip Vital yang telah disusun dalam Kotak Arsip Sumber: Dokumen Pribadi

DAS dan berkas arsip fisiknya, lalu diurutkan sesuai dengan kode wilayah dari berkas tersebut dan dilakukan proses scanning. Setelah tersedia berkas arsip dalam bentuk digital, dilakukan pengecekan kembali sebagai verifikasi terkait kebenaran berkas dan kesesuaian dengan DAS. Berkas arsip vital dalam bentuk digital yang telah dicek langsung disimpan kedalam folder komputer, lalu setelah berkas yang ada dalam satu kode wilayah selesai didigitalisasi maka langsung dilakukan proses pengunggahan kePersonal Computer(PC) Server Pertamina dengan menggunakan E-Arsip. E-Arsip

E-Arsip Pertamina sendiri merupakan Sistem Aplikasi Kearsipan berbasis web yang terpasang dalam server localhost milik Pertamina, serta digunakan sebagai sarana dan alat bantu untuk merekam dan mengelola setiap arsip vital yang dimiliki oleh Pertamina.Direktorat Manajemen Data Aset PT Pertamina menggunakan 
perangkat PC sebagai Mini Server untuk mendukung penggunaan E-Arsip sebagai Sistem Informasi Pengelolaan Arsip Vital yang ditempatkan di daerah Plumpang, Jakarta Utara. E-Arsip dirancang oleh Pertamina yang bekerjasama dengan PT Astra Graphia, sekaligus sebagai hasil dari proses kerjasama yang terjalin antara kedua belah pihak. Sistem Informasi EArsip ini bersifat proprietary, yang berarti merupakan sistem informasi dengan hak milik yang tidak bisa digunakan atau dimodifikasi secara sembarangan tanpa ada persetujuan dari pihak yang memiliki hak atas kepemilikan sistem yaitu PT Pertamina serta pihak pengelola sistem yaitu PT Astra Graphia.

Sistem Informasi E-Arsip ini dibangun dengan menggunakan bahasa pemrograman PHP sebagai dasarnya dan dijalankan dengan program web server mandiri bernama XAMPP (Crossplatform, Apache, MariaDB, PHP \& Perl). XAMPP merupakan aplikasi dukungan untuk menciptakan web server yang

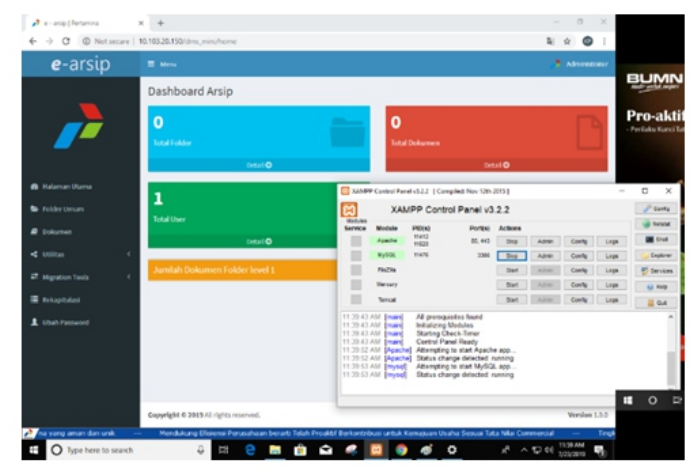

Foto 2

Tampilan Antar Muka (User Interface) dan Server dari E-Arsip.

Sumber: Dokumen Pribadi mandiri dan bisa diakses tanpa menggunakan jaringan internet global. Sistem jaringan yang digunakan adalah Intranet Pertamina sehingga hanya bisa diakses oleh internal Pertamina itu sendiri.Setiap komponen program yang membentuk E-Arsip ini dapat terlihat bahwa keamanan dan akses untuk dokumen arsip vital dapat terjamin karena program E-Arsip bersifat proprietary software, selain itujaringan untuk mengakses hanya dapat digunakan melalui akses intranet Pertamina yang berada dalam ruang lingkup kerja Pertamina.

Sistem Informasi E-Arsip dapat membantu setiap unit kerja yang ada dalam lingkungan manajemen aset untuk mencapai pelaksanaan pengawasan terhadap pemrosesan dokumen arsip vitalagar dapat dilakukan dengan mudah dan cepat. Fungsi lain E-Arsip adalah membantu pencarian dokumen arsip vital kapan saja dan dimana saja selama masih dalam satu jaringan Sistem Informasi EArsip yang ada dalam Intranet Pertamina, serta dapat membantu membuat laporan atau rekapitulasi untuk menunjang tugas pokok dan fungsi bagian di setiap Unit Kerja. 
Setiap Fungsi Menu yang ada dalam E-Arsip tersebut memiliki peranannya masing-masing untuk mengolah dan mengelola setiap dokumen yang ada. Dokumen-dokumen yang tercatat dalam E-Arsip bisa berbentuk fisik maupun digital, hal ini didukung dengan kolom lokasi objek dokumen yang menyebutkan secara rinci letak dan kondisi dokumen yang tercatat.Sistem Klasifikasi E-Arsip menggunakan standar kebijakan yang diterapkan oleh Direktorat Manajemen Data Aset, yang memiliki susunan sebagai berikut:

1. Klasifikasi dariUnit Kerja, menggunakan standar penomoran Kode Wilayah - Nomor Generik Unit Kerja(Contoh : 31-7207); dan

2. Dokumen Arsip Vital yang ada dalam suatu unit kerja menggunakan standar penomoran Gedung Sentral.Nomor Lantai.Nomor Ruang. Nomor Lemari/Rak.Nomor Baris.Nomor

Kolom, contohnya seperti berikut :GS1.A5.1.1.1.

Penentuan klasifikasi serta index dari arsip vital tersebut dilakukan oleh Direktorat Manajemen Data Aset untuk menerapkan kemudahan penyimpanan serta penemuan kembali suatu dokumen baik secara digital maupun fisik (dokumen fisik biasanya berupa peta, blueprint, rancangan kerja dan lain-lain). Standar klasifikasi dan indeks arsip vitalsudah diterapkan sejak lama bahkan sebelum PT
Pertamina mengusung konsep paperless.Jadwal Retensi Arsip (JRA) dari arsip vital secara fisik sudah ditentukan sebelumnya dalam kebijakan internal PT Pertamina, sedangkan arsip vital yang berbentuk digital akan menyesuaikan kebutuhan internal dan bersifat kondisional.

\section{Analisis}

Sistem Informasi dalam pengelolaan arsip harus dirancang secara baik dan menghasilkan sistem yang fleksibel dan extended, yang artinya mudah untuk beradaptasi dengan jenis koleksi arsip yang dimiliki serta bisa dilakukan pembaruan dan pemasangan fitur-fitur yang diperlukan kedepannya. Perangkat server juga harus mendukung sistem informasi yang telah dipasang mulai dari peforma hingga kapasitas perangkat yang harus sesuai.

Terbitan New York State Archives and Records Administrations(1990)yang berjudul Management of Electronic Records: Issue and Guidelines, tentang beberapa poin utama yang perlu disiapkan untuk merancang sistem informasi penyimpanan dokumen elektronik. Penulis akan melakukan analisis dari kebijakan dan juga penggunaan sistem informasi yang sudah diterapkan oleh Pertamina dalam hal pengelolaan arsip milik mereka. Poin-poin tersebut diantaranya adalah:

1. Prevent DataLoss 
Mencegah terjadinya kehilangan data harus selalu menjadi standar pola pikir yang ditekankan kepada para pengelola arsip dan dokumen. Segala hal yang berkaitan dengan pemeliharaan arsip dan dokumen harus selalu dilakukan semaksimal mungkin agar tidak terjadi hal-hal yang tidak diinginkan di kemudian hari. Prevent Data Loss harus menjadi poin utama yang dipikirkan dalam membangun suatu sistem penyimpanan arsip dan dokumen.

Belum adanya sistem terpadu untuk pencegahan hilangnya data secara digital, namun Direktorat Manajemen Aset memiliki beberapa tindakan pencegahan kehilangan data secara digital dengan menerapkan sistem backup perminggu. Tim IT PT Pertamina (Persero) dapat menangani tindakan pencegahan data secara digital (soft file) dengan memasang beberapa sistem keamanan dan restorasi untuk dokumen digital dan software, dan secara fisik (hardware \& devices) dengan melakukan maintenance serta pengecekan peforma perangkat.

2. Offer Adequete Capacity that can easily be increased as Storage needs Grow

Arsip dan dokumen akan selalu bertambah dan diproduksi setiap saat, sehingga lokasi dan kapasitas tempat penyimpanan pun akan terus bertambah serta berkembang. Mencari skema sistem informasi penyimpanan arsip dan dokumen yang bisa menawarkan penambahan kapasitas penyimpanan tentu menjadi hal selanjutnya yang harus dilakukan, sehingga nantinya dokumen yang baru dibuat atau diproduksi bisa menjadi arsip yang disimpan di kemudian hari. Adanya hal ini, maka pencegahan terhadap data-data yang hilang bisa ditanggulangi seminimal mungkin, apabila sistem penyimpanan belum bisa ditambah kapasitasnya mungkin saja dokumen baru tersebut disimpan di sembarang tempat lalu pada saat akan menjadi arsip ternyata hilang begitu saja karena sistem yang saat itu sudah penuh kapasitasnya dan dokumen yang disimpan dimana saja hilang.

PC Server PT Pertamina mendukung pembaruan dan penambahan perangkat sehingga poin ini bisa terlaksana dengan mudah. Hal ini dikarenakan tersedia banyak perangkat yang bisa disediakan oleh PT Pertamina untuk menambahkan kapasitas tempat penyimpanan sesuai dengan jumlah dokumen yang dimiliki dan diproduksi. PT Pertamina juga menggunakan SSD (Solid-state Drive) 
yang mampu menampung lebih banyak koleksi digital serta meningkatkan kecepatan read and write dari satu dokumen digital.

3. Provide Fast Access to Data without Interruptions

Kemudahan dan kecepatan dalam mengakses suatu data maupun informasi tentu menjadi nilai penting dalam ruang lingkup organisasi, hal ini merupakan dasar dari kebutuhan yang tidak bisa diganggu gugat. Terjadinya gangguan atau lambatnya proses akses dan penyediaan informasi akan sangat menghambat kinerja organisasi, sehingga diperlukan adanya solusi untuk menyediakan akses data yang cepat dan baik tanpa ada gangguan untuk memaksimalkan kinerja dan produktivitas organisasi.

PT Pertamina memiliki jaringan intranet yang terhubung dalam masing-masing gedung milik mereka, sehingga kecepatan akses data cukup baik untuk melakukan akses dan pengambilan data secara real-time. Hal ini dikarenakan intranet merupakan jaringan lokal yang mendukung kecepatan akses yang lebih tinggi dan tanpa adanya waktu downtime selama akses dilakukan dalam ruang lingkup jaringan PT Pertamina.

4. Beprepared for Equipment Failures

Mempersiapkan perangkat lain atau perangkat cadangan untuk menanggulangi permasalahan yang terjadi akibat dari kerusakan perangkat secara fisik (hardware). Apabila dilain hari terjadi kerusakan maka bisa langsung diganti dan proses pengelolaan akan normal dalam waktu yang cepat.

Perangkat pendukung yang dimiliki oleh PT Pertamina saat ini cukup banyak dan bisa dilakukan penambahan kembali apabila diperlukan. Selain itu untuk menanggulangi kejadian dalam kerusakan yang terjadi pada perangkat fisik, tim pengelola server E-Arsip selalu melakukan pemeliharaan secara berkala dalam jangka waktu yang telah ditentukan.

5. Use Cost-effective Technologies

Pemanfaatan teknologi yang rendah pengeluarannya cukup ditekankan dalam beberapa aspek apabila organisasi memiliki banyak beban biaya yang ditanggung oleh mereka. Hal ini juga bisa bermanfaat bagi organisasi, karena akan menghemat biaya pengeluaran dan biaya perbaikan sehingga setiap biaya yang telah disimpan bisa digunakan untuk keperluan lainnya yang lebih memiliki benefit.

Sistem Aplikasi E-Arsip yang digunakan memanfaatkan teknologi perangkat lunak yang bersifat gratis 
dan open-source seperti XAMPP dan sistem yang dibangun dengan bahasa pemrograman PHP sehingga sudah termasuk dalam kategori Costeffective. Kedua komponen ini telah membantu pengelola dalam menurunkan pengeluaran biaya yang dikeluarkan karena setiap komponen yang ada dalam E-Arsip merupakan komponen open-source yang bisa dengan mudah digunakan dan dimodifikasi.

Selain dari poin-poin dari ketentuan yang telah dibuat oleh PBB mengenai sistem informasi penyimpanan arsip, penulis juga memiliki matriks yang berupa Assessment Form dan bisa digunakan untuk mengukur seberapa baik dan efektif E-Arsip dimanfaatkan oleh para pengelola atau pengguna E-Arsip untuk mengelola arsip vital secara digital.

Assessment Form ini terdiri dari tiga subjek utama yang mencakup setiap aspek dari masing-masing kategori yang secara lazim dimiliki oleh sistem informasi kearsipan. Tiga Subjek ini meliputi bagian administrasi dan keamanan, tampilan antarmuka pengguna (Graphic User Interface) serta konten arsip.

\section{Administrasi dan Keamanan}

a. Otentikasi dan Verifikasi

E-Arsip sudah dibekali dengan sistem akun dan verifikasi akses lewat halaman login sehingga untuk bagian otentikasi serta verifikasi ini sudah cukup baik.

b. Hak Akses Sistem Informasi

E-Arsip menggunakan jaringan intranet lokal milik PT Pertamina sehingga hak akses yang diberikan hanya dikhususkan bagi internal Pertamina serta pejabat pengelolaan arsip yang telah ditetapkan. Maka sudah direncanakan secara matang untuk pemberian hak akses Sistem Informasi E-Arsip ini.

Tabel 1. Assesment Form untuk E-Arsip

\begin{tabular}{|c|c|c|c|}
\hline No. & Subjek & Aspek & Keterangan \\
\hline \multirow[t]{7}{*}{1} & \multirow{7}{*}{$\begin{array}{l}\text { Administrasi \& } \\
\text { Keamanan }\end{array}$} & Otentikasi \& Verifikasi & Tersedia \\
\hline & & Hak Akses Sistem Informasi & Tersedia \\
\hline & & Prosedur Penggunaan Sistem Informasi & Tersedia \\
\hline & & Kebijakan Access Role & Tersedia \\
\hline & & Kebijakan Penggunaan Akun Akses & Tersedia \\
\hline & & Perencanaan Cadangan Data (Backup) & Tahap Perencanaan \\
\hline & & Berkas Terstruktur & Tersedia \\
\hline \multirow[t]{4}{*}{2} & \multirow{4}{*}{$\begin{array}{l}\text { Tampilan } \\
\text { Antarmuka } \\
\text { Pengguna }\end{array}$} & Kemudahan Penggunaan & Terpenuhi \\
\hline & & Tata Letak Menu Operasional & Terpenuhi \& Sesuai \\
\hline & & Preview Berkas Arsip Elektronik & Belum Tersedia \\
\hline & & Diagram/Chart Kuantitas Koleksi & Dalam format angka, belum ada Diagram/Chart \\
\hline \multirow[t]{5}{*}{3} & \multirow[t]{5}{*}{ Konten Arsip } & Kesesuaian Metadata & Terpenuhi \& Sesuai \\
\hline & & Dukungan Standar Format Berkas & Terpenuhi (format berkas excel) \\
\hline & & Unduh Berkas Digital & Tersedia \\
\hline & & Jadwal Retensi & Penyesuaian \\
\hline & & Import/Export Berkas Arsip & Tersedia \\
\hline
\end{tabular}

Sumber: Analisis Peneliti 
c. Prosedur Penggunaan Sistem Informasi Saat ini E-Arsip memiliki panduan dan dokumentasi sistem yang terpasang didalamnya lewat berkas BRD (Business Requirement Development) yang telah disusun oleh PT Astra Graphia selaku pengembang E-Arsip.

d. Kebijakan Access Role

E-Arsip memiliki fitur untuk membatasi dan memberikan hak-hak akses terhadap beberapa menu dan juga dokumen, sehingga bisa secara baik melindungi data-data dari pihak-pihak yang tidak memiliki wewenang atas dokumen arsip vital yang ada dalam E-Arsip.

e. Kebijakan Penggunaan Akun Akses

Direktorat Manajemen Aset dan fungsi lainnya memiliki akun masing-masing untuk melakukan akses ke E-Arsip ini, sehingga penggunaan akses untuk masingmasing akun dari fungsi hanya berlaku bagi yang memiliki otoritas dan berada dalam fungsi tersebut.

f. Perencanaan Cadangan Data (Backup)

Cadangan data direncanakan kedepannya setelah seluruh dokumen arsip berhasil didigitalisasi dan disimpan secara baik di E-Arsip. Dalam fase digitalisasi, dilakukan pencadangan data dengan jumlah tertentu dalam satu minggu. g. Sistem Klasifikasi Berkas Terstruktur Sistem Berkas yang terstruktur sesuai dengan jenis berkas serta ruang lingkup wilayah berkas bisa diimplementasikan kedalam EArsip, selain itu diterapkan juga sistem indeks yang memberikan kode unik sesuai dengan data berkas sehingga akan dengan mudah mencari berkas berdasarkan lokasi maupun nomor panggil berdasarkan indeks. Nama berkas disusun sesuai dengan nomor dokumen generik dengan format Kode Wilayah Nomor Generik (contoh :317207) lalu untuk sistem indeks akan menunjukkan lokasi penyimpanan dokumen dengan format Gedung Sentral.Nomor Lantai.Nomor Ruang.Nomor Lemari/Rak.Nomor Baris.Nomor Kolom sehingga penulisannya menjadi seperti berikut : GS1.A5.1.1.1.

\section{Tampilan Antarmuka Pengguna}

a. Kemudahan Penggunaan

Tampilan dari E-Arsip memudahkan penggunaan dan pengelolaan secara lebih efektif.

b. Tata Letak Menu Operasional Tata letak dari setiap menu yang terpasang cukup bagus serta terdapat fitur minimize untuk menghilangkan bar menu agar bisa melihat workspace secara lebih luas. 
c. Preview Berkas Arsip Elektronik Untuk saat ini belum ada fitur preview dalam E-Arsip. Fitur ini bisa dinilai penting karena bisa memudahkan pengelola melihat dan mengecek berkas tanpa perlu mengunduhnya terlebih dahulu.

d. Diagram/Chart Kuantitas Koleksi

E-Arsip memiliki kolom kuantitas jumlah koleksi arsip, pengelola dan total folder yang telah dibuat. Saat ini belum ada tampilan kuantitas dalam bentuk diagram atau chart.

\section{Konten Arsip}

a. Kesesuaian Metadata

Metadata yang digunakan dalam EArsip sesuai dengan jenis koleksi dokumen arsip vital yang dimiliki oleh PT Pertamina.

b. Dukungan Standar Format Berkas

E-Arsip mendukung format berkas standar excel yaitu xlsx, sehingga cukup memenuhi untuk standar format berkas yang digunakan.

c. Unduh Berkas

Tersedia unduhan berkas untuk format laporan.

d. Jadwal Retensi

Penyesuaian JRA dilakukan sesuai dengan kondisi fisik arsip.

e. Import/Export Berkas Arsip

E-Arsip memiliki fitur untuk melakukan impor dan juga ekspor koleksi sehingga lebih memudahkan untuk melakukan input dalam jumlah yang banyak dan juga lebih mudah untuk dibuat sebagai laporan.

\section{KESIMPULAN}

Pengelolaan aset-aset perusahaan yang termasuk dalam bagian dari arsip vital milik PT Pertamina saat ini tengah digalakkan secara masif, karena sebelumnya aset-aset ini tidak dipandang sebagai sesuatu yang penting oleh beberapa direktorat. Sayangnya dalam organisasi ini tidak ada jabatan secara struktural yang berperan sebagai arsiparis maupun pustakawan untuk mengatur dan mengelola berkas dan koleksi arsip vital yang dimiliki, sehingga pelaksanaan pengelolaan berkas arsip vital untuk keperluan administratif menjadi agak terhambat. Mulai tahun 2019 Direktorat Manajemen Aset mulai mengumpulkan dan mengolah setiap arsip-arsip vital yang dimiliki oleh PT Pertamina dan mulai melakukan digitalisasi untuk seluruh koleksi arsip yang dimiliki serta mencoba bertransformasi untuk membangun dan memanfaatkan akses secara digital untuk sistem pengelolaan arsip. Akibat dari kekurangan tenaga dalam pengelolaan arsip P T Pertamina harus mempertimbangkan untuk melakukan penambahan anggota pengelola secara administratif dan fungsional agar pengelolaan arsip vital ini bisa berjalan dengan lancar tanpa ada hambatan. Hal ini akan sangat membantu roda kegiatan yang dilakukan oleh PT Pertamina dalam 
setiap hal yang membutuhkan dokumen atau arsip perusahaan, seperti keperluan pengembangan, riset, status legal, kepemilikan dan masih banyak lagi lainnya. Maka dengan bertambahnya anggota pengelola arsip ini akan meningkatkan kinerja dan efisiensi dari seluruh kegiatan yang dilakukan oleh PT Pertamina.

Sistem Informasi Pengelolaan yang dimiliki oleh PT. Pertamina yaitu E-Arsip, saat ini masih belum digunakan secara penuh karena beberapa koleksi arsip vital saat ini masih berbentuk fisik dan perlu dilakukan digitalisasi secara berkala. Hal ini dikarenakan jumlah total seluruh Arsip adalah sekitar 1.100.000 lembar dan belum diperiksa serta digitalisasi secara keseluruhan. Sistem Informasi E-Arsip sudah bisa dikatakan siap untuk menampung seluruh koleksi arsip vital yang dimiliki oleh PT Pertamina. Beberapa aspek sudah terpenuhi dan juga untuk pembaruan serta perubahan sistemnya kedepan dapat dilakukan secara optimal untuk beradaptasi dengan arsip vital yang akan diunggah.E-Arsip juga bisa digunakan untuk mengelola beberapa arsip lain yang berkaitan namun mungkin tidak akan terlalu optimal karena PT Astra Graphia dan P T P e r tamina mengoptimalisasi E-Arsip dengan hanya dikhususkan untuk arsip vital saja. Berdasarkan lembar penilaian (Assessment Form) yang dibuat oleh penulis berdasarkan beberapa kriteria standar arsip elektronik dari UNESCO dan Arsip Nasional Republik Indonesia (ANRI), EArsip sudah memenuhi standar sistem informasi kearsipan walaupun masih ada beberapa fitur yang perlu ditambahkan untuk menunjang kegiatan pengelolaan arsip.

\section{DAFTAR PUSTAKA}

Undang-Undang Republik Indonesia Nomor 43 tahun 2009 tentang Kearsipan, Jakarta.

bin Ladjamudin, A.-B., \& Ladjamudin, A.B. bin. (2005). Analisis dan Desain Sistem Informasi. Yogyakarta: Graha Ilmu.

Kemp, T. J. (2017). International Vital Records Handbook. 7th Edition: Births, Marriages, Deaths.Genealogical Publishing Co. Genealogical Publishing Co.

Mulyanto, A. (2009). Sistem Informasi Konsep dan Aplikasi. Yogyakarta: Pustaka Pelajar.

Prastowo, A. (2016). Memahami Metodemetode Penelitian, Suatu Tinjauan Teoritis dan Praktis. Yogyakarta: Ar Ruzz Media.

Sujarwadi, V. W. (2014). Metodologi Penelitian. Yogyakarta: Pustaka Baru Press.

Sukoco, B. M. (2006). Manajemen Administrasi Perkantoran Modern. Jakarta: Erlangga.

United Nations Educational Scientific and Cultural Organization. (1990). Management of Electronic Records: Issue and Guidelines. United States, New York 